\title{
Tidskapsel: Pædagogisk alvor
}

Morten Misfeldt ${ }^{1}$, Institut for Naturfagenes Didaktik og Datalogisk Institut, Københavns Universitet

2020 har været et mærkeligt år på den pædagogiske front, så jeg synes, ideen med at lægge lidt i en tidskapsel er god, den bidrager jeg gerne til. Mit bidrag er nok farvet af, at jeg har været meget involveret i Københavns Universitets opfølgning og evaluering af forårets overgang til onlineundervisning. Dette arbejde har blandt andet vist, hvor krævende en forandring overgangen har været, hvor stort et arbejde det har været for underviserne, og hvor vanskeligt det har været for de studerende at arbejde under de forandrede rammer. Samtidigt har der været en række nye muligheder og måske især et kæmpe kapacitetsryk vedrørende onlineundervisning. Vi er stadig i gang med at samle og analysere data fra nedlukningen, så i stedet for at forsøge at fremmane præmature konklusioner vil jeg benytte lejligheden her til at reflektere lidt mere frit over, hvad der egentligt skete med digital undervisning i 2020.

Jeg har arbejdet med implementering af digitale teknologier i undervisningssystemet i det meste af mit arbejdsliv. Jeg har haft fokus på de kreative muligheder i digitale metoder og værktøjer og på de problemer, der kan opstå, når undervisningen benytter disse, uden at fagforståelser og opgaveformuleringer følger med. Derudover har jeg arbejdet en del med de organisatoriske rammer omkring digitalisering - blandt andet har jeg studeret implementering af grundskolens famøse læringsplatforme, der sammenknyttet med skolereform og målstyret undervisning blandt andet gav anledning til en stor portion af den triste sovs af mistillid, der desværre kan opstå i samspillet mellem politik, effektivisering, arbejdsforhold, ledelse og digitalisering.

Alligevel synes jeg, at 2020 har været et alvorens år for pædagogisk it. Digital undervisning ophørte fra den ene dag til den anden med at være et mere eller mindre eksotisk alternativ, der i nogle situationer er forstyrrende, og $\mathrm{i}$ andre situationer potentielt fremmer undervisningens effektivitet. I stedet blev den til en situation, hvor mantraet "digitaliseringen af undervisningen bør studeres som et vilkår, snarere end som en binær beslutning (digitaliser eller ej), som kalder på et entydigt effektorienteret svar fra forskningen" gik fra at være akademisk tågesnak for de indviede til noget, som ethvert barn i mellemskolen kunne se var indlysende sandt.

Alvoren har først og fremmest bestået i, at de materielle rammer for undervisningssituationen er blevet ændret så meget og så hurtigt, at vanerne og al den tavse viden, der normalt holder undervisningspraksis sammen, brød ned. Vi kunne ikke trække på sidste års plan, på vores erfaring eller på den didaktiske fantasi, som vi har opbygget ved at have gode lærere, undervise med gode kolleger, få feedback osv. Alle har været tvunget til at tænke anderledes på deres undervisning, ved at tænke meget i både medier og værktøjer. Skal min undervisning være i Teams eller i Zoom? Skal jeg optage den på forhånd eller undervejs? Men også ved at tænke mere abstrakt på undervisningen. Hvad er det vigtigste, de studerende skal have med? Hvordan sikrer jeg mig, at de

\footnotetext{
${ }^{1}$ Kontakt: misfeldt@ind.ku.dk
} 
opnår det, når jeg ikke kan regne med at se dem allesammen? Pædagogiske og didaktiske begreber har derfor været mere nødvendige og alvorlige for arbejdet som underviser, end de plejer.

Alvoren har desuden bestået $\mathrm{i}$, at det er blevet meget tydeligt, at uddannelsesinstitutioner varetager nogle helt centrale sociale funktioner, der er nødvendige for børn og unges trivsel. De trivselsproblemer, som undersøgelser af fx skolebørn og gymnasieelever, men også universitetsstuderende, har blotlagt, er substantielle og bør tages ekstremt alvorligt. I hvor høj grad der er tale om nye fænomener, eller om vi snarere ser en acceleration af problematikker og bevægelser, der har været i gang de sidste mange år, vil jeg her undlade at gætte på. Men alvorligt er det i hvert fald.

Det blev også året, hvor digital undervisning for alvor skulle stå sin prøve. Hvad kan man så med alt det der digitale? Duer det til noget, og kan det overhovedet sammenlignes i kvalitet med almindelig undervisning? Sammenligningen er naturligvis tarvelig og urimelig. Alle vil hellere være fri for pandemi og have lov til at komme i skole/hen på uddannelsesinstitutionen. Men spørgsmålet om, hvad der skal med videre efter pandemien, stilles alle steder.

Endelig blev det også lige pludselig alvor - forstået som her og nu, frem for noget der kunne udskydes til senere - for en hel masse undervisere. Mange har fået digital debut som undervisere, og den pædagogiske/didaktiske sektor som sådan har på den måde fået et kapacitetsløft, der indtil marts i år ville have oversteget de vildeste fantasier i ethvert digitaliseringskontor.

2020 blev altså året, hvor it og undervisning blev alvor.

\section{Betingelser for brug af denne artikel}

Denne artikel er omfattet af ophavsretsloven, og der må citeres fra den.

Følgende betingelser skal dog være opfyldt:

- Citatet skal være i overensstemmelse med "god skik"

- Der må kun citeres „i det omfang, som betinges af formålet"

- Ophavsmanden til teksten skal krediteres, og kilden skal angives ift. ovenstående bibliografiske oplysninger

(C) Copyright

DUT og artiklens forfatter
Udgivet af Dansk Universitetspædagogisk Netværk 